\title{
PENGARUH VOLUME PENYIRAMAN PUPUK CAIR URINE SAPI TERHADAP PERTUMBUHAN DAN PRODUKSI TANAMAN CABAI MERAH BESAR (Capsicum annum L)
}

\author{
Ona Sitra Adu ${ }^{1}$ dan Alwi Smith ${ }^{2}$ \\ ${ }^{1}$ Alumni Program Studi Pendidikan Biologi \\ ${ }^{2}$ Dosen Program Studi Pendidikan Biologi \\ E-mail: alwi_smith@yahoo.com
}

\begin{abstract}
Background: Organic fertilizers is able to maintain the balance of the land and improve land productivity as well as reducing the environmental impact of land. Pepper plants contain lots of vitamin A and vitamin $\mathrm{C}$ and contain essential oils capsaicin, which causes a spicy flavor and heat to provide warmth when used for spices (herbs).

Methods: The materials used in this study is the land of black, red chilli seeds large, EM4, water immersion soy, turmeric and wastewater cow urine. The study was conducted over three months, from April 2015 - July 2015. This study used a completely randomized design (CRD) with a liquid treatment factors limbar cow urine at levels as follows: $P 0=$ control, $M L P 1=25, P 2=50 \mathrm{ML}$ and $\mathrm{P} 3=75 \mathrm{ML}$. Each treatment was repeated 3 times. Data were analyzed using analysis of variance and if there is an influence, it will be followed by Least Significant Difference Test (BNT) at significance level of $5 \%$ and $1 \%$.

Results: The results showed that administration of cow urine liquid waste significant effect on the growth of large red pepper plant, that plant height, fruit number and weight of the fruit harvest.

Conclusion: The growth of large red pepper plant with the highest scores were obtained in treatment P3 with a concentration of $75 \mathrm{ml}$ while the growth to the lowest value was obtained in treatment P1 with a concentration of $25 \mathrm{ml}$.
\end{abstract}

Keywords: Liquid waste of cow urine, Growth Big Red Chili.

\begin{abstract}
Abstrak
Latar Belakang: Pupuk organik mampu menjaga keseimbangan lahan dan meningkatkan produktifitas lahan serta mengurangi dampak lingkungan tanah. Tanaman cabai banyak mengandung vitamin $A$ dan vitamin $\mathrm{C}$ serta mengandung minyak atsiri capsaicin, yang menyebabkan rasa pedas dan memberikan kehangatan panas bila digunakan untuk rempah-rempah (bumbu dapur).

Metode: Bahan-bahan yang digunakan dalam penelitian ini adalah tanah hitam, benih cabai merah besar, EM4, air rendaman kedelai, kunyit dan limbah cair urine sapi. Penelitian ini dilakukan selama 3 bulan, mulai dari April 2015 - Juli 2015. Penelitian ini menggunakan Rancangan Acak Lengkap (RAL) dengan satu faktor perlakuan limbar cair urine sapi dengan tingkatan sebagai berikut: $P_{0}=$ kontrol, $P_{1}=$ $25 \mathrm{ML}, \mathrm{P}_{2}=50 \mathrm{ML}$, dan $\mathrm{P}_{3}=75 \mathrm{ML}$. Masing-masing perlakuan diulang sebanyak 3 kali. Data yang diperoleh dianalisis menggunakan analisis varians dan apabila terdapat pengaruh, maka akan dilanjutkan dengan Uji Beda Nyata Terkecil (BNT) pada taraf signifikan $5 \%$ dan $1 \%$.

Hasil: Hasil penelitian menunjukkan bahwa pemberian limbah cair urine sapi memberikan pengaruh yang nyata terhadap pertumbuhan tanaman cabai merah besar, yaitu pada tinggi tanaman, jumlah buah dan bobot buah panen.

Kesimpulan: Pertumbuhan tanaman cabai merah besar dengan nilai tertinggi diperoleh pada perlakuan $\mathrm{P}_{3}$ dengan konsentrasi $75 \mathrm{ml}$ sedangkan pertumbuhan dengan nilai terendah diperoleh pada perlakuan $\mathrm{P}_{1}$ dengan konsentrasi $25 \mathrm{ml}$.
\end{abstract}

Kata kunci: Limbah cair urine sapi, Pertumbuhan Cabai Merah Besar. 


\section{PENDAHULUAN}

Cabai merah besar merupakan tanaman perdu dari famili terong-terongan (Solanaceae) yang memiliki nama ilmiah Capsicum annum dan tanaman yang mudah ditanam di dataran rendah ataupun di dataran tinggi. Tanaman cabai banyak mengandung vitamin $\mathrm{A}$ dan vitamin $\mathrm{C}$ serta mengandung minyak atsiri capsaicin, yang menyebabkan rasa pedas dan memberikan kehangatan panas bila digunakan untuk rempah- rempah (bumbu dapur). Cabai dapat ditanam dengan mudah sehingga bisa dipakai untuk kebutuhan sehari-hari tanpa harus membelinya di pasar (Harpenas, 2010).

Untuk meningkatkan dan menjaga kestabilan produksi pertanian, khususnya tanaman pangan sangat perlu diterapkan tekhnologi yang murah dan mudah bagi petani. Teknologi tersebut dituntut ramah lingkungan dan dapat dimanfaatkan seluruh potensi sumber daya alam yang ada dilingkungan pertanian, sehingga tidak memutus rotasi sistem pertanian (Prajananta, 1993).

Pupuk organik mampu menjaga keseimbangan lahan dan meningkatkan produktifitas lahan serta mengurangi dampak lingkungan tanah (Sutanto, 2006). Salah satunya adalah dengan memanfaatkan pupuk yang berasal dari kotoran hewan seperti urine sapi. Hal ini disebabkan dalam urine sapi terdapat kandungan hara $\mathrm{N}, \mathrm{P}, \mathrm{K}$ dan air yang lebih banyak dibandingkan dengan kotoran padat (Supriadji, 1985). Banyak penelitian yang telah dilakukan terhadap urine sapi, diantaranya adalah Buckman H. O. dan N. C. Brady (1982) melaporkan bahwa urine sapi mengandung zat perangsang tumbuh yang dapat digunakan sebagai pengatur tumbuh diantaranya adalah IAA. Lebih lanjut dijelaskan bahwa urine sapi juga memberikan pengaruh positif terhadap pertumbuhan vegetatif tanaman jagung (Dwiwarni, 1989 dalam Setyowati, 2004).

Urine sapi merangsang pertumbuhan akar pada setek karena urine sapi mengandung auksin $a$, auksin $b$ dan IAA (hetero auksin). Jaringan tanaman yang dikonsumsi sapi banyak mengandung auksin a, dan IAA. Auksin ini tidak dapat dicernakan dalam tubuh sapi sehingga terbuang bersama keluarnya air kemih. Dengan demikian secara tidak langsung urine sapi dapat menggantikan fungsi hormon tumbuh sintetis yang berasal dari IBA dan Rootone F (Supriadji, 1985).

\section{METODE}

Penelitian ini menggunakan tipe penelitian eksperimen lapangan (field Eksperiment) yang berarti eksperimen yang dilakukan untuk mendeteksi hubungan sebab akibat dalam lingkungan alami dimana peristiwa terjadi secara normal. Penelitian ini berlangsung selama \pm 3 bulan dari bulan April sampai dengan bulan Juli 2015 dan berlokasi di Green House Pendidikan Biologi Universitas Pattimura Ambon. Objek dalam penelitian ini adalah cabai merah besar. Untuk sampel bibit, digunakan 21 gram cabai merah besar. Untuk sampel pengamatan diambil 10 tanaman cabai. Pengambilan sampel dilakukan secara purposive sampling. Data yang diperoleh dianalisis menggunakan Analisis Sidik Ragam Lengkap (Analisis Varians) (Hanafiah, 2005). Dengan kriteria penerimaan hipotesis sebagai berikut: Terima $\mathrm{H}_{0}$, jika $\mathrm{F}_{\mathrm{Hit}}<\mathrm{F}_{\mathrm{Tab}}$, dan tolak $\mathrm{H}_{0}$, jika $\mathrm{F}_{\text {Hit }}>\mathrm{F}_{\mathrm{Tab}}$. Kemudian dilanjutkan dengan uji BNT pada taraf $\alpha=0,05$ dan $\alpha=0,01$, untuk mengetahui perbedaan masingmasing perlakuan.

\section{HASIL DAN PEMBAHASAN Hasil}

Data rata-rata tinggi tanaman cabai merah besar untuk minggu ke -2 , minggu ke4 , minggu ke- 6 minggu ke-8, dan minggu ke10 dapat dilihat pada tabel 1 dan 2 . 
Tabel 1. Rata-rata Tinggi Tanaman Cabai Merah Besar minggu ke-2, Setelah Penyiraman Pupuk Cair Urine Sapi.

\begin{tabular}{cc}
\hline Perlakuan & Rata-Rata Tinggi Tanaman Cabai (cm) \\
\hline P0 & 7,5 \\
P1 & 10,3 \\
P2 & 11,23 \\
P3 & 9,96 \\
\hline
\end{tabular}

Keterangan

$\mathrm{P}_{0}$ : Kontrol tanpa pupuk cair urine sapi

$\mathrm{P} 1_{1}$ : Volume urine sapi $25 \mathrm{ml}$

$\mathrm{P} 2$ : Volume urine sapi $50 \mathrm{ml}$

$\mathrm{P}_{1}$ : Volume urine sapi $75 \mathrm{ml}$

Tabel 1 menunjukan bahwa rata-rata tinggi tanaman Cabai merah besar untuk minggu ke -2 dengan nilai tertinggi $12,5 \mathrm{~cm}$ diperoleh pada perlakuan penyiraman sedangkan rata-rata tinggi tanaman dengan nilai terendah $7,5 \mathrm{~cm}$ pada kontrol. Rata-rata tinggi tanaman cabai merah besar lebih jelas terlihat pada histogram (gambar 1).

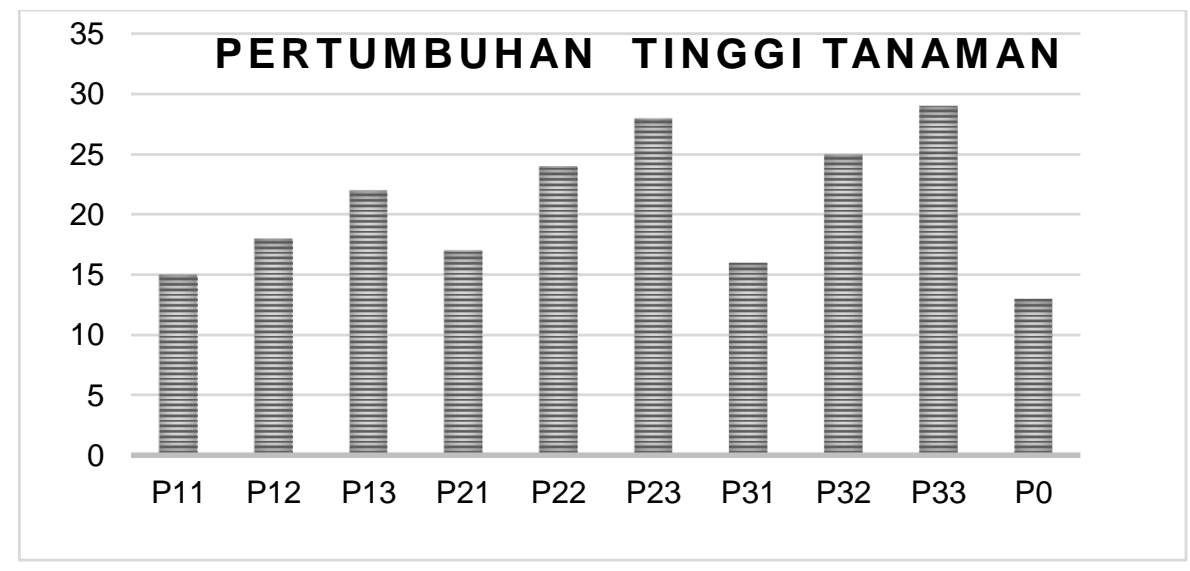

\section{Gambar 1. Histogram Rata-rata Tinggi Tanaman Cabai Merah Besar k -2.}

Berdasarkan gambar 1, histogram tinggi cabai merah besar dengan kombinasi perlakuan $\mathrm{P}_{2}$ mempunyai nilai rata-rata tertinggi $12,5 \mathrm{~cm}$ dibandingkan dengan $\mathrm{P} 1_{1}$,
$\mathrm{P} 1_{2}, \mathrm{P} 1_{3}, \mathrm{P} 2_{1}, \mathrm{P} 2_{2}, \mathrm{P} 3_{1}, \mathrm{P} 3_{2} \mathrm{P}_{2}$. Analisis varians tinggi tanaman cabai merah besar pada minggu ke-2 dapat dilihat pada tabel 2 .

Tabel 2. Analisis Varians Tinggi Cabai Merah Besar Minggu Ke-2.

\begin{tabular}{ccccccc}
\hline Sumber & \multirow{2}{*}{ JK } & \multirow{2}{*}{ KT } & \multirow{2}{*}{ F hitung $_{n n y y}$} & \multicolumn{2}{c}{ F Tabel } \\
Keragaman & & & & $\mathbf{0 , 0 5}$ & $\mathbf{0 , 0 1}$ \\
\hline Perlakuan & 43,69 & 14,5 & $3,46^{*}$ & 2,27 & 3,48 \\
Acak & 12,60 & & & & & \\
\hline Total & 56,29 & & & & \\
\hline
\end{tabular}

KK $=19 \%$

Keterangan * ${ }^{*}$ Berpengaruh nyata

Berdasarkan analisis tinggi tanaman (Capsicum annum. L) yang diperlihatkan pada tabel 2. bahwa pengaruh penyiraman pupuk cair urine sapi berpengaruh nyata
$\left(F_{\text {hitung }}>F_{\text {tabel }}\right)$ pada taraf 0,05 terhadap tinggi tanaman cabai merah besar. Nilai $F_{\text {hitung }} 3,46$ dan $F_{\text {tabel }} 2,27$. Hasil uji BNT pengaruh penyiraman pupuk cair urine sapi terhadap 
terhadap pertumbuhan dan produksi tanaman cabai merah besar dapat dilihat pada tabel 3.

Tabel 3. Hasil Uji BNT Minggu Ke-2

\begin{tabular}{cccccc}
\hline Perlakuan & Rara-rata & $\begin{array}{c}\text { Selisih Terhadap } \\
\text { Kontrol }\end{array}$ & \multicolumn{2}{c}{ Uji BNT } \\
\cline { 5 - 6 } & 7,5 & $\mathbf{0 , 0 5}$ & $\mathbf{0 , 0 1}$ \\
\hline P0 & 10,3 & $2,8^{\mathrm{TN}}$ & & \\
P1 & 11,23 & $3,73^{* *}$ & & 2,27 & 3,48 \\
P2 & 9,96 & $2,46^{*}$ & & \\
\hline P3 & &
\end{tabular}

Berdasarkan hasil uji BNT yang diperlihatkan pada tabel 3. terlihat bahwa selisih nilai terhadap kontrol pada perlakuan $\mathrm{P} 1<$ Uji BNT. Ini menunjukan bahwa penyiraman pupuk cair urine sapi pada perlakuan $\mathrm{P} 1$ tidak memberikan pengaruh yang nyata terhadap pertumbuhan tinggi tanaman cabai merah besar. Sedangkan pada perlakuan P2 selisih nilai terhadap kontrol > nilai Uji BNT pada taraf kepercayaan $5 \%$ dan $1 \%$. Ini menunjukan bahwa penyiraman pupuk cair urine sapi memberikan pengaruh yang sangat nyata terhadap pertumbuhan tanaman cabai merah besar minggu ke-2 pada taraf kepercayaan $1 \%$ dan $5 \%$. Pada perlakuan P3 selisih nilai terhadap kontrol > nilai Uji BNT hanya pada taraf kepercayaan $5 \%$. Sebaliknya tidak memberikan pengaruh yang nyata pada tingkat kepercayaan $1 \%$. Ini menunjukan bahwa penyiraman pupuk cair urine sapi memberikan pengaruh yang nyata terhadap pertumbuhan tanaman cabai minggu ke-2. Rata-rata tinggi tanaman cabai merah besar untuk minggu ke-4 dari setiap perlakuan di perlihatkan pada tabel 4 .

Tabel 4. Rata-rata Tinggi Tanaman Cabai Merah Besar Minggu Ke-4 (cm).

\begin{tabular}{cc}
\hline Perlakuan & Rata-Rata Tinggi Tanaman Cabai (cm) \\
\hline P0 & 13 \\
P1 & 18,9 \\
P2 & 23,7 \\
P3 & 23,8 \\
\hline
\end{tabular}

Tabel 4 menunjukan bahwa tinggi tanaman Cabai merah besar pada setiap perlakuan untuk minggu ke -4 tertinggi dengan nilai $29,7 \mathrm{~cm}$ diperoleh pada perlakuan penyiraman pupuk cair urine sapi
$75 \mathrm{ml}$. Sedangkan tinggi tanaman dengan nilai terendah pada kontrol $13 \mathrm{~cm}$. Rata-rata tinggi tanaman cabai merah besar lebih jelas terlihat pada histogram (gambar 2).

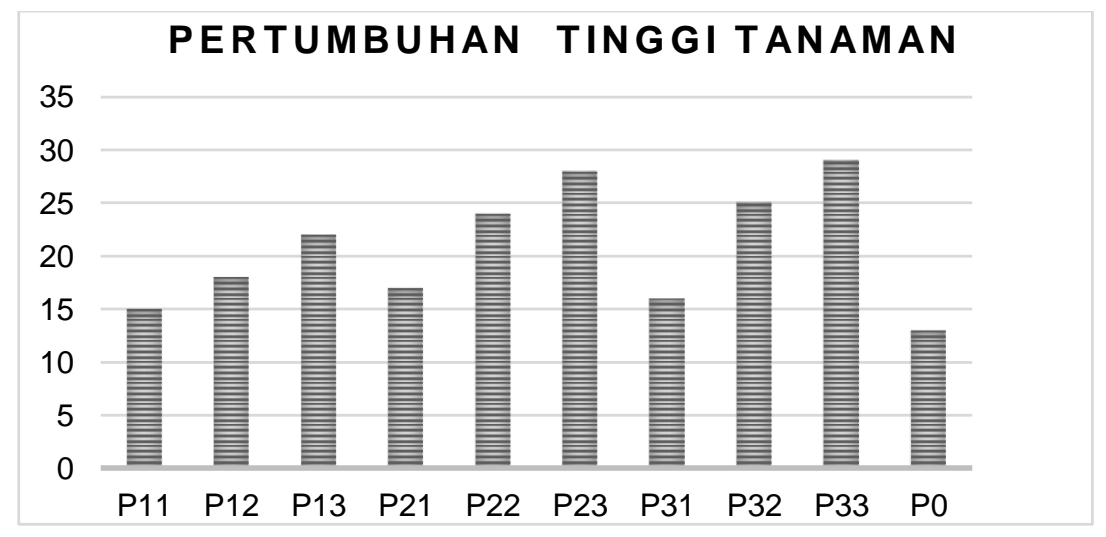

Gambar 4.2. Histogram Rata-rata Tinggi Tanaman Cabai Merah Besar 
Berdasarkan gambar 2, histogram tinggi tanaman cabai merah besar dengan perlakuan $\mathrm{P}_{3}$ mempunyai nilai rata-rata tertinggi 29,7 dibandingkan dengan $\mathrm{P} 1_{1}, \mathrm{P}_{2}$,
$\mathrm{P} 1_{3}, \mathrm{P} 2_{1}, \mathrm{P} 2_{2}, \mathrm{P} 2_{3}, \mathrm{P} 3_{1}, \mathrm{P} 3_{2}$. Analisis varians tinggi tanaman cabai merah besar pada minggu ke-4 diperlihatkan pada tabel 5 berikut.

Tabel 5. Analisis Varians Tinggi (Capsicum annum L) Minggu Ke-4.

\begin{tabular}{ccccccc}
\hline Sumber & \multirow{2}{*}{ DB } & \multirow{2}{*}{ JK } & \multirow{2}{*}{ KT } & \multirow{2}{*}{ F hitung } & \multicolumn{2}{c}{ F Tabel } \\
\cline { 6 - 7 } Keragaman & & & & 0,05 & $\mathbf{0 , 0 1}$ \\
\hline Perlakuan & 3 & 356,5 & 188,8 & $27,1^{* *}$ & 17,87 & 26,01 \\
Acak & 8 & 131,6 & & & & \\
Total & 11 & 488,1 & & & & \\
\hline
\end{tabular}

KK $=14,4 \%$

Keterangan ${ }^{* *}=$ Sangat berpengaruh nyata

Berdasarkan analisis tinggi tanaman cabai merah besar yang diperlihatkan pada tabel 4.5 bahwa pengaruh perlakuan penyiraman pupuk cair urine sapi sangat berpengaruh nyata $\left(F_{\text {hitung }}>F_{\text {tabel }}\right)$ terhadap tinggi tanaman (Capsicum annum L). Nilai $F_{\text {hitung }} 27,1$ dan $F_{\text {tabel }} 17,87$. Hasil uji BNT pengaruh penyiraman pupuk cair urine sapi terhadap tinggi tanaman cabai merah besar dapat dilihat pada tabel 6 .

Tabel 6. Hasil Uji BNT Minggu Ke-4.

\begin{tabular}{ccccc}
\hline \multirow{2}{*}{ Perlakuan } & Rara-rata & $\begin{array}{c}\text { Selisih Terhadap } \\
\text { Kontrol }\end{array}$ & \multicolumn{2}{c}{ Uji BNT } \\
\cline { 4 - 5 } & 13 & & & $\mathbf{5} \%$ \\
P0 & 18,9 & $5,9^{\mathrm{TN}}$ & & \\
P1 & 22,3 & $9,3^{\mathrm{TN}}$ & 17,87 & 26,01 \\
P2 & 17,5 & $4,5^{\mathrm{TN}}$ & & \\
P3 & & & & \\
\hline
\end{tabular}

Berdasarkan hasil uji BNT yang diperlihatkan pada tabel 4.6 terlihat bahwa selisih nilai dengan kontrol pada perlakuan perlakuan $\mathrm{P} 1-\mathrm{P}_{3}<$ dari nilai uji BNT. Ini menunjukan bahwa pemberian volume pupuk cair urine sapi tidak memberikan pengaruh terhadap pertumbuhan tanaman cabai merah besar minggu ke-4. Rata-rata tinggi tanaman cabai merah besar untuk minggu ke-6 dari setiap perlakuan di perlihatkan pada tabel 6 .

Rata-rata tinggi tanaman cabai merah besar untuk minggu ke-6 dari setiap perlakuan di perlihatkan pada tabel 7.

Tabel 7. Rata-rata Tinggi Tanaman Cabai Merah Besar Minggu Ke-6 (cm).

\begin{tabular}{cc}
\hline Perlakuan & Rata-Rata Tinggi Tanaman $\mathbf{( c m )}$ \\
\hline P0 & 35 \\
P1 & 53,03 \\
P2 & 56,9 \\
P3 & 57,7 \\
\hline
\end{tabular}

Tabel 7 menunjukan bahwa tinggi tanaman cabai merah besar pada setiap perlakuan untuk minggu ke -6 tertinggi dengan nilai 59,6 cm diperoleh pada pengaruh penyiraman pupuk cair urine sapi
$\mathrm{P}_{3}$. Sedangkan tinggi tanaman dengan nilai terendah $33 \mathrm{~cm}$ pada perlakuan $\mathrm{P}_{0}$. Ratarata tinggi tanaman cabai merah besar lebih jelas terlihat pada histogram (gambar 3). 


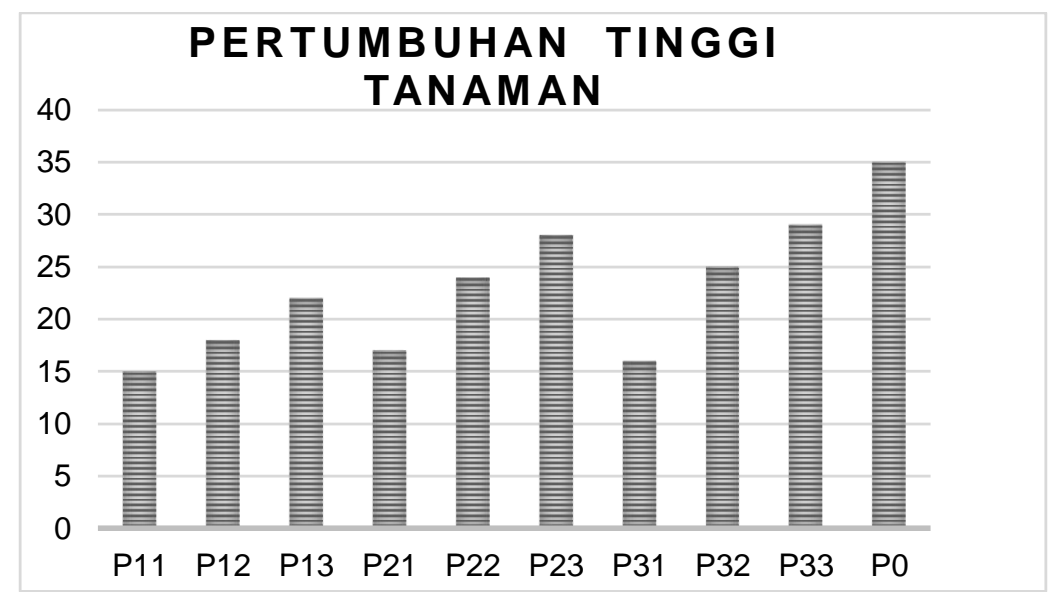

\section{Gambar 3. Histogram Rata-rata Tinggi Tanaman Cabai Merah Besar Minggu Ke-6.}

Berdasarkan Gambar 3. histogram tinggi tanaman cabai merah besar dengan volume penyiraman $75 \mathrm{ml}$ mempunyai nilai rata-rata tertinggi $59,6 \mathrm{~cm}$ dibandingkan dengan $\mathrm{P} 1_{1}, \mathrm{P} 1_{2} \mathrm{P} 1_{3}, \mathrm{P} 2_{1}, \mathrm{P} 2_{2}, \mathrm{P} 2_{3}, \mathrm{P} 3_{1}, \mathrm{P} 3_{2}$. Analisis varians tinggi tanaman cabai merah besar pada minggu ke- 6 diperhatikan pada tabel 8.

Tabel 8. Analisis Varians Tinggi Tanaman Cabai Merah Besar Minggu Ke-6

\begin{tabular}{ccccccc}
\hline $\begin{array}{c}\text { Sumber } \\
\text { Keragaman }\end{array}$ & DB & JK & \multirow{2}{*}{ KT } & \multirow{2}{*}{ F hitung } & \multicolumn{2}{c}{$\mathbf{F}$ Tabel } \\
\hline Perlakuan & 3 & 613 & 204,3 & $14,5^{* *}$ & 8,17 & $\mathbf{0 , 0 1}$ \\
Acak & 8 & 423,2 & & & & \\
\hline Total & 11 & 1036,2 & & & & \\
\hline
\end{tabular}

$\mathrm{KK}=10 \%$

Keterangan ${ }^{* *}=$ Sangat berpengaruh nyata

Berdasarkan analisis tinggi tanaman (Capsicum annum L) yang diperlihatkan pada tabel 8 . bahwa pengaruh penyiraman volume pupuk cair urine sapi sangat berpengaruh nyata $\left(F_{\text {hitung }}>F_{\text {tabel }}\right)$ terhadap tinggi tanaman (Capsicum annum L). Nilai $F_{\text {hitung }} 14,5$ dan $F_{\text {tabel }} 8,17$. Hasil uji BNT pengaruh volume penyiraman pupuk cair urine sapi terhadap tinggi tanaman cabai merah besar dapat dilihat pada tabel 9 .

Tabel 4.9. Hasil Uji BNT Minggu Ke-6

\begin{tabular}{ccccc}
\hline \multirow{2}{*}{ Perlakuan } & Rata-Rata & Beda Terhadap & \multicolumn{2}{c}{ Uji BNT } \\
\cline { 5 - 5 } & & $\mathbf{5} \%$ & $\mathbf{1} \%$ \\
\hline P0 & 35 & & & \\
P1 & 53,03 & $18,3^{* *}$ & 8,17 & 11,9 \\
P2 & 56,9 & $21,9^{* *}$ & & \\
P3 & 57,7 & $19,7^{* *}$ & & \\
\hline
\end{tabular}

Berdasarkan hasil uji BNT yang diperlihatkan pada tabel 4.9 terlihat selisih nilai terhadap kontrol pada perlakuan dengan nilai rata-rata $P_{1}-P_{3}>$ dari nilai uji BNT. Ini menunjukan bahwa volume penyiraman pupuk cair urine sapi memberikan pengaruh yang sangat nyata pada taraf kepercayaan $1 \%$ dan $5 \%$ terhadap pertumbuhan tanaman cabai merah besar pada minggu ke-6. Rata-rata tinggi tanaman cabai merah besar untuk minggu ke-8 dari setiap perlakuan di perlihatkan pada tabel 10 . 
Tabel 10. Rata-rata Tinggi Tanaman Cabai Merah Besar Minggu Ke-8 (cm)

\begin{tabular}{cc}
\hline Perlakuan & Rata-Rata Tinggi Tanaman Cabai (cm) \\
\hline P0 & 49,3 \\
P1 & 73,2 \\
P2 & 68,4 \\
P3 & 49,3 \\
\hline
\end{tabular}

Tabel 10 menunjukan bahwa tinggi tanaman cabai merah besar pada setiap perlakuan untuk minggu ke -8 tertinggi dengan nilai $79,5 \mathrm{~cm}$ diperoleh pada volume penyiraman pupuk cair urine sapi $25 \mathrm{ml}$. sedangkan tinggi tanaman dengan nilai terendah $49,3 \mathrm{~cm}$ pada kontrol. Rata-rata tinggi tanaman cabai merah besar lebih jelas terlihat pada histogram (gambar 4).

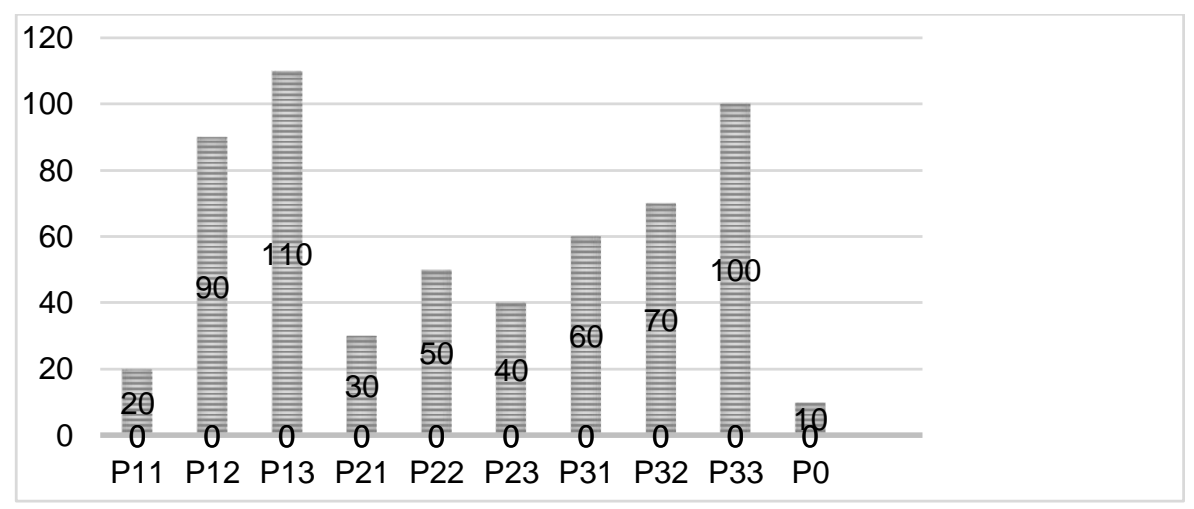

\section{Gambar 4. Histogram Rata-rata Tinggi Tanaman Cabai Merah Besar Minggu Ke-8.}

Berdasarkan gambar 4 histogram tinggi tanaman cabai merah besar dengan volume penyiraman $75 \mathrm{ml}$ mempunyai nilai rata-rata tertinggi $78,9 \mathrm{~cm}$ dibandingkan dengan $\mathrm{P} 1_{1}$,
$\mathrm{P} 1_{2}, \mathrm{P} 1_{3}, \mathrm{P} 2_{1}, \mathrm{P} 2_{2}, \mathrm{P} 2_{3}, \mathrm{P} 3_{1}, \mathrm{P} 3_{2}$. Analisis varians tinggi tanaman pada minggu ke-8 diperhatikan pada tabel 11 .

Tabel 11. Analisis Varians Tinggi (Capsicum annum L) Minggu Ke-8

\begin{tabular}{|c|c|c|c|c|c|c|}
\hline \multirow{2}{*}{$\begin{array}{c}\text { Sumber } \\
\text { Keragaman }\end{array}$} & \multirow{2}{*}{ DB } & \multirow{2}{*}{ JK } & \multirow{2}{*}{ KT } & \multirow{2}{*}{$F_{\text {hitung }}$} & \multicolumn{2}{|c|}{ F Tabel } \\
\hline & & & & & 0,05 & 0,01 \\
\hline Perlakuan & 3 & 266,13 & 88,71 & $0,17^{\mathrm{TN}}$ & & \\
\hline Acak & 8 & 368,7 & & & 69,4 & 100,9 \\
\hline Total & 11 & 635 & & & & \\
\hline
\end{tabular}

$\mathrm{KK}=23 \%$

Keterangan $\mathrm{TN}=$ Tidak berpengaruh nyata

Berdasarkan analisis tinggi tanaman (Capsicum annum L) yang diperlihatkan pada tabel 11 bahwa pengaruh volume penyiraman pupuk cair urine sapi tidak berpengaruh nyata $\left(F_{\text {hitung }}<F_{\text {tabel }}\right)$ terhadap tinggi tanaman (Capsicum annum L). Nilai $F_{\text {hitung }} 0,17$ dan $F_{\text {tabel }} 69,4$. Hasil uji BNT pengaruh volume penyiraman pupuk cair urine sapi terhadap pertumbuhan tanman dapat dilihat pada tabel 12 . 
Tabel 12. Hasil Uji BNT Minggu Ke-8.

\begin{tabular}{ccccc}
\hline \multirow{2}{*}{ Perlakuan } & Rara-rata & $\begin{array}{c}\text { Beda terhadap } \\
\text { kontrol }\end{array}$ & \multicolumn{2}{c}{ F Tabel } \\
\cline { 5 - 6 } & 49,3 & & $\mathbf{0 , 0 5}$ & $\mathbf{0 , 0 5}$ \\
\hline P0 & 64,3 & $15^{\mathrm{TN}}$ & & \\
P1 & 75,8 & $26,5^{\mathrm{TN}}$ & 69,4 & 100,9 \\
P2 & 79,5 & $30,2^{\mathrm{TN}}$ & & \\
P3 & & &
\end{tabular}

Berdasarkan hasil uji BNT yang diperlihatkan pada tabel 13. terlihat bahwa selisih nilai terhadap kontrol pada perlakuan $\mathrm{P} 1$ - P3 < nilai uji BNT pada taraf $5 \%$ dan 1 $\%$. Hal ini menunjukan bahwa pengaruh volume penyiraman pupuk cair urine sapi tidak berbeda nyata pada pertumbuhan tanaman cabai merah besar minggu ke-8. Rata-rata tinggi tanaman cabai merah besar untuk minggu ke-10 dari setiap perlakuan di perlihatkan pada tabel 13 .

\section{Tabel 13. Rata-rata Tinggi Tanaman Cabai Merah Besar Minggu Ke-10 (cm).}

\begin{tabular}{cc}
\hline Perlakuan & Rata-Rata Tinggi Tanaman Cabai (cm) \\
\hline $\mathrm{P} 0$ & 67,8 \\
$\mathrm{P} 1_{1}$ & 98,6 \\
$\mathrm{P} 1_{2}$ & 96,7 \\
$\mathrm{P} 1_{3}$ & 104 \\
\hline
\end{tabular}

Tabel 13 menunjukan bahwa tinggi tanaman cabai merah besar pada setiap perlakuan untuk minggu ke -10 tertinggi dengan nilai $110,3 \mathrm{~cm}$ diperoleh pada volume penyiraman pupuk cair urine sapi 75 $\mathrm{ml}$ sedangkan tinggi tanaman dengan nilai terendah $74 \mathrm{~cm}$ pada perlakuan PO. Ratarata tinggi tanaman cabai merah besar lebih jelas terlihat pada histogram (gambar. 5).

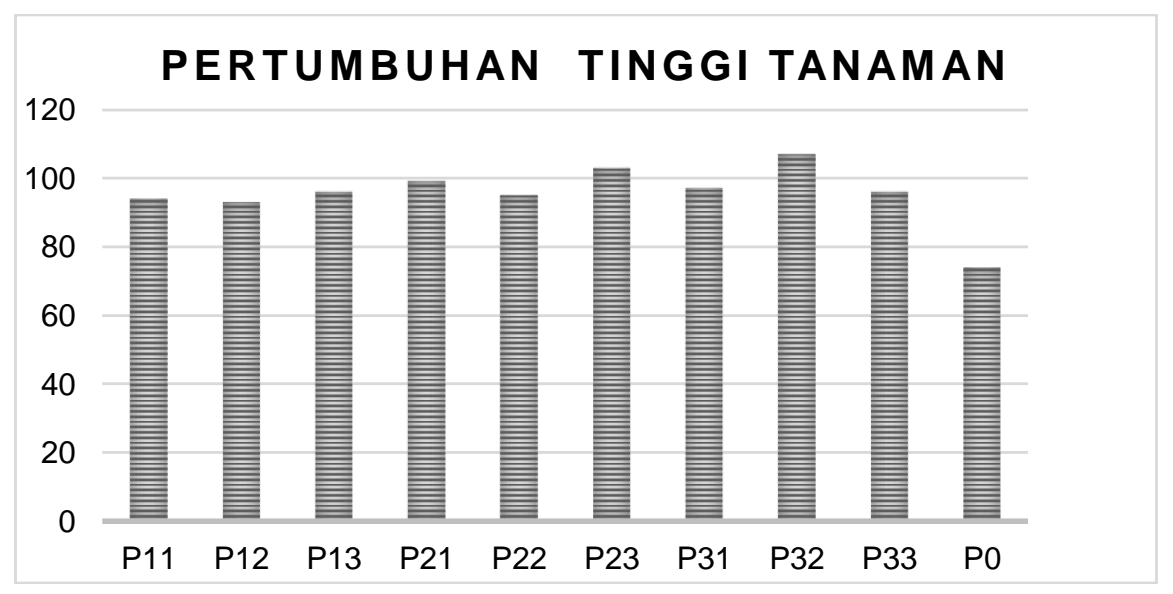

Gambar 5. Histogram Rata-rata Tinggi Tanaman Cabai Merah Besar Minggu Ke-10.

Berdasarkan gambar 5, histogram tinggi tanaman cabai merah besar dengan perlakuan $\mathrm{P}_{3}$ mempunyai nilai rata-rata tertinggi $110,3 \mathrm{~cm}$ dibandingkan dengan $\mathrm{P} 1_{1}$,
$\mathrm{P} 1_{2}, \mathrm{P} 1_{3}, \mathrm{P} 2_{1}, \mathrm{P} 2_{2}, \mathrm{P} 2_{3}, \mathrm{P} 3_{1}, \mathrm{P} 3_{2}$. Analisis tinggi tanaman (Capsicum annum L) pada minggu ke-10 diperhatikan pada tabel 14 . 
Tabel 14. Analisis Varians Tinggi (Capsicum annum. L) Minggu Ke-10.

\begin{tabular}{|c|c|c|c|c|c|c|}
\hline \multirow{2}{*}{$\begin{array}{c}\text { Sumber } \\
\text { Keragaman }\end{array}$} & \multirow{2}{*}{ DB } & \multirow{2}{*}{ JK } & \multirow{2}{*}{$\mathrm{KT}$} & \multirow{2}{*}{$F_{\text {hitung }}$} & \multicolumn{2}{|c|}{ F Tabel } \\
\hline & & & & & 0,05 & 0,01 \\
\hline Perlakuan & 3 & 47 & 15,6 & $12,08^{* *}$ & & \\
\hline Acak & 8 & 3,89 & & & 7,32 & 10.63 \\
\hline Total & 11 & 50,89 & & & & \\
\hline
\end{tabular}

$\mathrm{KK}=0,9 \%$

Keterangan ${ }^{* *}=$ Sangat berpengaruh nyata

Berdasarkan analisis tinggi tanaman (Capsicum annmum L) yang diperlihatkan pada tabel 14. bahwa pengaruh volume penyiraman pupuk cair urine sapi sangat berpengaruh nyata $\left(F_{\text {hitung }}>F_{\text {tabel }}\right)$ terhadap tinggi tanaman (Capsicum annum L). Nilai $F_{\text {hitung }} 12,08$ dan $F_{\text {tabel }} 7,32$. Hasil uji BNT pengaruh volume penyiraman pupuk cair urine sapi terhadap pertumbuhan tanaman dapat dilihat pada tabel 15.

Tabel 15. Hasil Uji BNT Minggu Ke-10

\begin{tabular}{ccccc}
\hline \multirow{2}{*}{ Perlakuan } & Rata-Rata & \multirow{2}{*}{$\begin{array}{c}\text { Beda Terhadap } \\
\text { Kontrol }\end{array}$} & \multicolumn{2}{c}{ Uji BNT } \\
\cline { 4 - 5 } & & & $\mathbf{5 \%}$ & $\mathbf{1} \%$ \\
\hline P0 & 67,8 & $30,8^{* *}$ & & \\
P1 & 98,6 & $28,9^{* *}$ & 7,32 & 10,63 \\
P2 & 96,7 & $36,2^{* *}$ & & \\
P3 & 104 & & & \\
\hline
\end{tabular}

Berdasarkan hasil uji BNT yang diperlihatkan pada tabel 15 . dapat dilihat bahwa selisih nilai terhadap kontrol pada perlakuan P1 - P3 > nilai Uji BNT. Ini menunjukan bahwa pengaruh volume penyiraman pupuk cair urine sapi sangat berpengaruh nyata pada tinggi tanaman cabai merah besar tingkat kepercayaan $1 \%$ dan $5 \%$ pada minggu ke- 10 .

\section{Jumlah Buah (Capsicum annum L)}

Data hasil perhitungan jumlah buah pada setiap kombinasi perlakuan dari setiap ulangan ditunjukan pada lampiran 12. Sedangkan rata-rata jumlah buah setiap perlakuan dapat dilihat pada tabel 4.16.

Tabel 16. Rata-rata Jumlah Buah Capsicum annum L.

\begin{tabular}{cc}
\hline Perlakuan & Rata-Rata Jumlah Buah \\
\hline P0 & 17 \\
P1 & 18 \\
P2 & 21 \\
P3 & 19 \\
\hline
\end{tabular}

Tabel 16 menunjukan bahwa jumlah buah cabai merah besar pada setiap perlakuan yang tertinggi dengan nilai 31 buah diperoleh pada volume penyiraman pupuk cair $75 \mathrm{ml}$. sedangkan jumlah buah dengan nilai terendah 12 pada kontrol. Ratarata jumlah buah cabai merah besar lebih jelas terlihat pada histogram. 


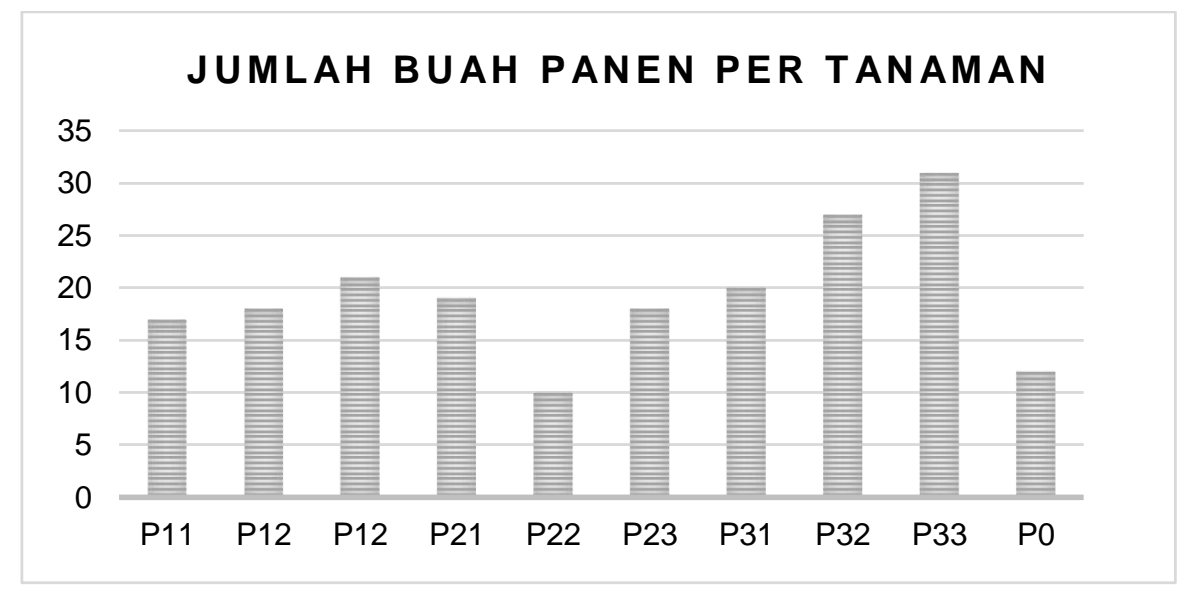

Gambar 7. Histogram Rata-rata Jumlah Buah Cabai Merah Besar

Berdasarkan gambar 7, histogram jumlah buah cabai merah besar dengan perlakuan $\mathrm{P}_{3}(75 \mathrm{ml})$ mempunyai nilai rata- rata tertinggi 31 buah dibandingkan dengan $\mathrm{P} 1_{1}, \mathrm{P} 1_{2}, \mathrm{P}_{1}, \mathrm{P} 2_{1}, \mathrm{P} 2_{2}, \mathrm{P} 2_{3}, \mathrm{P} 3_{1}, \mathrm{P} 3_{2}$.

Tabel 17. Analisis Varians Jumlah Buah (Capsicum annum L)

\begin{tabular}{ccccccc}
\hline Sumber & \multirow{2}{*}{ DB } & JK & \multirow{2}{*}{ KT } & \multirow{2}{*}{ F $_{\text {hitung }}$} & \multicolumn{2}{c}{ F Tabel } \\
\cline { 6 - 7 } Keragaman & & & & $\mathbf{0 , 0 5}$ & $\mathbf{0 , 0 1}$ \\
\hline Perlakuan & 3 & 86,2 & 28,7 & $10,26^{\mathrm{TN}}$ & & \\
Acak & 8 & 8,4 & & & 15,79 & 22,9 \\
Total & 11 & 94,6 & & & & \\
\hline
\end{tabular}

$\mathrm{KK}=1 \%$

Keterangan $\mathrm{TN}=$ Tidak berpengaruh nyata

Berdasarkan analisis tinggi tanaman (Capsicum annum L) yang diperlihatkan pada tabel 17 . bahwa pengaruh volume penyiraman volume pupuk cair urine sapi tidak berpengaruh nyata $\left(F_{\text {hitung }}<F_{\text {tabel }}\right)$ terhadap jumlah buah tanaman (Capsicum annum $\mathrm{L})$. Nilai $\mathrm{F}_{\text {hitung }} 10,26$ dan $\mathrm{F}_{\text {tabel }} 15,79$. Analisis jumlah buah (Capsicum annum $\mathrm{L}$ ) dapat diperhatikan pada tabel 18.

Tabel 18. Hasil Uji BNT Jumlah Buah Capsicum annum L

\begin{tabular}{ccccc}
\hline \multirow{2}{*}{ Perlakuan } & Rata-Rata & \multirow{2}{*}{$\begin{array}{c}\text { Beda Terhadap } \\
\text { Kontrol }\end{array}$} & \multicolumn{2}{c}{ Uji BNT } \\
\cline { 4 - 5 } & 12 & & $\mathbf{5} \%$ & $\mathbf{1 \%}$ \\
\hline P0 & 18,6 & $6,6^{\mathrm{TN}}$ & & \\
P1 & 18,6 & $6,6^{\mathrm{TN}}$ & 15,79 & 22,9 \\
P2 & 9,96 & $7^{\mathrm{TN}}$ & & \\
P3 & & & & \\
\hline
\end{tabular}

Berdasarkan hasil Uji BNT yang diperlihatkan pada tabel 18. dapat dilihat bahwa selisih nilai terhadap kontrol pada perlakuan P1 - P3 > nilai Uji BNT. Ini menunjukan bahwa penyiraman volume pupuk cair urine sapi pada taraf $5 \%$ dan $1 \%$ tidak memberikan pengaruh yang nyata terhadap jumlah buah cabai merah besar.

\section{Bobot Buah Panen (Capsicum annum} L)

Data hasil perhitungan bobot buah cabai merah besar pada setiap perlakuan volume penyiraman pupuk cair urine sapi dari setiap ulangan. Sedangkan rata-rata bobot buah setiap perlakuan dapat dilihat pada tabel 19. 
Tabel 19. Rata-rata Bobot Cabai Merah Besar (Capsicum annum L)

\begin{tabular}{cc}
\hline Perlakuan & Rata-Rata Jumlah Buah Cabai \\
\hline P0 & 23,81 \\
P1 & 30,10 \\
P2 & 28,50 \\
P3 & 40,26 \\
\hline
\end{tabular}

Tabel 19 menunjukkan bahwa bobot Cabai merah besar per gram pada setiap perlakuan yang tertinggi dengan nilai 50,28 diperoleh pada pengaruh perlakuan volume penyiraman urine sapi $\mathrm{P}_{3} \quad(75 \mathrm{ml})$.
Sedangkan bobot buah dengan nilai terendah 23,81 pada kontrol. Rata-rata bobot cabai merah besar lebih jelas terlihat pada histogram (gambar 7).

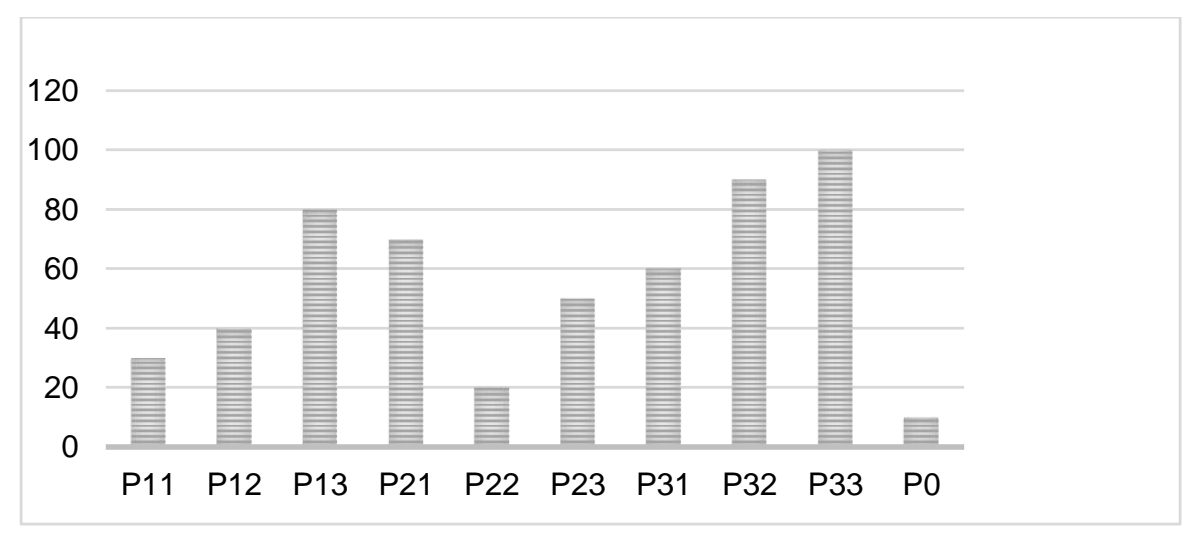

Gambar 7. Histogram Rata-rata Bobot Buah Cabai Merah Besar.

Berdasarkan Gambar 7. histogram bobot buah cabai merah besar dengan perlakuan $\mathrm{P}_{3}$ mempunyai nilai rata-rata tertinggi 50,28 dibandingkan dengan P0,
$\mathrm{P} 1_{1}, \mathrm{P} 1_{2}, \mathrm{P} 1_{3}, \mathrm{P} 2_{1}, \mathrm{P} 2_{2}, \mathrm{P} 2_{3}, \mathrm{P} 3_{1}, \mathrm{P} 3_{2}$. Analisis bobot buah (Capsicum annum L) dapat diperhatikan pada tabel 19.

Tabel 19. Analisis Bobot Buah Cabai Merah Besar (Capsicum annum L)

\begin{tabular}{|c|c|c|c|c|c|}
\hline \multirow{2}{*}{$\begin{array}{c}\text { Sumber } \\
\text { keragaman }\end{array}$} & \multirow{2}{*}{ JK } & \multirow{2}{*}{$\mathbf{K T}$} & \multirow{2}{*}{$F_{\text {hitung }}$} & \multicolumn{2}{|c|}{ F Tabel } \\
\hline & & & & 0,05 & 0,01 \\
\hline Perlakuan & 197,9 & 65,9 & $1,66^{\mathrm{TN}}$ & & \\
\hline Acak & 119,2 & & & 224,3 & 326,4 \\
\hline Total & 317,15 & & & & \\
\hline
\end{tabular}

$\mathrm{KK}=5 \%$

Keterangan $\mathrm{TN}=$ Tidak berpengaruh nyata

Berdasarkan analisis bobot buah (Capsicum annum L) yang diperlihatkan pada tabel 19 bahwa pengaruh volume penyiraman pupuk cair urine sapi tidak berpengaruh nyata $\left(F_{\text {hitung }}<F_{\text {tabel }}\right)$ terhadap bobot buah tanaman (Capsicum annum L). Nilai $F_{\text {hitung }} 1,66$ dan $F_{\text {tabel }} 224,3$. Analisis bobot buah (Capsicum annum L) dapat diperhatikan pada tabel 20. 
Tabel 20. Hasil Uji BNT Bobot buah Capsicum annum L

\begin{tabular}{ccccc}
\hline \multirow{2}{*}{ Perlakuan } & Rata-Rata & Beda Terhadap & \multicolumn{2}{c}{ Uji BNT } \\
\cline { 4 - 5 } & & Kontrol & $\mathbf{1} \%$ & $\mathbf{5} \%$ \\
\hline P0 & 29,71 & $5,9^{\text {TN }}$ & 224,3 & 326,4 \\
P1 & 30,43 & $6,62^{\text {TN }}$ & & \\
P2 & 33,18 & $9,37^{\text {TN }}$ & & \\
P3 & 32,88 & $9,07^{\text {TN }}$ & & \\
\hline
\end{tabular}

Berdasarkan hasil uji BNT yang diperlihatkan pada tabel 20 dapat dilihat bahwa selisih nilai terhadap kontrol pada P1 - P3 yang nilainya < nilai uji BNT pada taraf kepercayaan $1 \%$ dan $5 \%$. Ini menunjukan bahwa pengaruh volume penyiraman pupuk cair urine sapi tidak berpengaruh nyata pada bobot buah tanaman cabai merah besar.

\section{Pembahasan}

Rosmarkam dan Narsih (2002), mengatakan bahwa kandungan yang terdapat didalam limbah berperan dalam merangsang pertumbuhan vegetatif yaitu menambah tinggi tanaman. Perkembangan sistem perakaran yang baik sangat menentukan pertumbuhan vegetatif tanaman yang pada akhirnya menentukan produksi tanaman yang baik. Jadi perlakuan yang terbaik pada penyiraman volume pupuk cair adalah volume $75 \mathrm{ml}$.

Pertumbuhan tanaman cabai merah besar dengan nilai terendah diperoleh pada perlakuan P1 (25 ml). hal ini dikarenakan kekurangan unsur hara yang diberikan pada tanaman cabai merah besar, menyebabkan pertumbuhan tanaman cabai menjadi kurang baik. Menurut Leibelam (1992) bahwa pertumbuhan dan produksi akan tinggi apabila didalam tanah terdapat unsur hara dengan jumlah yang seimbang dan laju pertumbuhan akan menurun apabila unsur hara yang diperlukan tidak tersedia.

Selain itu, penambahan pupuk cair urine sapi $75 \mathrm{ml}$ yang telah difermentasikan menyebabkan konsentrasi IAA mampu secara optimal memacu pertumbuhan tanaman. Mengenai kandungan hormon IAA pada urine sapi tersebut disebutkan oleh Solikun dan Masdiko (2000) bahwa fermentasi urine sapi secara ilmiah mengandung zat pengatuh tumbuh yaitu auksin golongan IAA.

Selain hormon yang dikandung pupuk cair urine sapi yang dapat memacu pertumbuhan tanaman unsur hara yang dikandungnya juga mempercepat proses pertumbuhan vegetatif tumbuhan. Pupuk organik cair sapi ini mengandung unsur Nitrogen, Pospor dan Kalium yang lebih tinggi dibanding pupuk organik cair lainnya. Selain unsur hara makro pupuk pupuk organik cair ini juga mengandung unsur hara mikro yang menyebabkan terpacunya pembelahan sel. Hal ini seperti yang dikemukakan Indrakusuma (2000), Salisbuny dan Ross (1995) menyatakan bahwa pupuk organik cair selain mengandung Nitrogen yang menyusun dari semua protein, asam nukleat dan klorofil juga mengandung unsur hara mikro antara lain Mn, Zn, Fe, S, B, Ca, dan Mg. unsur hara mikro tersebut berperan dalam proses sintesis protein dan pembentukan klorofil.

Pada Perlakuan P1 dan P2 $(25 \mathrm{ml}$, dan $50 \mathrm{ml}$ ) memiliki tingkat produksi dalam hal ini jumlah buah panen yang terendah dibandingkan dengan P3 (75 ml) karena nutrisi yang terdapat pada pupuk cair sapi tidak seimbang sehingga menyebabkan produksi tanaman cabai juga menurun, juga dipengaruhi meningkatnya aktivitas mikroorganisme sehingga unsur $\mathrm{N}$ tidak tersedia bagi tanaman karena terjadi imobilisasi unsur hara dalam tanah (Hariyadi, 1994).

Selain itu peningkatan jumlah buah panen juga dipengaruhi oleh proses penyiraman pupuk cair. Dimana penyiraman pupuk yang dilakukan pada penelitian ini diberikan langsung pada akar dan daun tanaman sehingga penyerapan nutrisi keseluruh bagian tanaman lebih optimal. Hal ini sesuai dengan pernyataan Rosmarkam dan Yuwono (2002) bahwa pemupukan lewat daun lewat saja seringkali tidak memuaskan karena nutrisi yang yang diserap daun tidak bergerak.

Hasil penelitian menunjukan bahwa bobot buah panen tanaman cabai merah besar pada perlakuan P3 (75 ml)) memiliki tingkat produksi tanaman dan bobot buah 
yang tertinggi. Hal ini dikarenakan nutrisi yang terkandung dalam pupuk cair urine sapi yang digunakan. Ketersediaan unsur hara yang cukup pada setiap fase pertumbuhan akan mengaktifkan proses fotosintesis, sehingga proses pembelahan, perpanjangan dan diferensiasi sel akan lebih baik, dengan demikian pertumbuhan maupun produksi tanaman akan meningkat (Syarief, 1986).

Dari hasil penelitian penyiraman pupuk cair urine sapi memberikan hasil yang nyata bagi pertumbuhan maupun produksi tanaman cabai merah besar. Hal ini karena limbah urine cair yang digunakan sudah terlebih dahulu mengalami proses fermentasi dengan penambahanbahanbahan yang akan lebih meningkatkan kandungan unsur hara makro dan mikro yang ada di dalam limbah cair.

\section{KESIMPULAN}

Berdasarkan hasil penelitian maka dapat disimpulkan bahwa:
1. Ada pengaruh pemberian volume pupuk cair urine sapi terhadap pertumbuhan dan produksi tanaman Capsicum annum.L.

2. Pemberian volume pupuk cair urine sapi yang paling berpengaruh adalah pada perlakuan $\mathrm{P}_{3}$ yaitu dengan volume 75 $\mathrm{ml}$ pupuk cair urine sapi.

\section{DAFTAR PUSTAKA}

Harpenas, Asep \& R. Dermawan. 2010. Budidaya Cabai Unggul. Penebar Swadaya: Jakarta.

Prajananta. 1993. Penggunaan Pupuk Pada Tanaman.

Salisbury, B. F. dan C. C.W Ross, 1995. Fisiologi Tumbuhan. Jilid 3 ITB: Bandung.

Supriadji, G. 1985. Air Kemih Sapi sebagai Perangsang Setek Kopi. Warta Penelitian dan Pengembangan Pertanian. 7(2): 11-12. Bogor.

Sutanto. 2002. Penerapan Pertanian organik. Kanisius: Yogyakarta. 